University of Nebraska - Lincoln

DigitalCommons@University of Nebraska - Lincoln

Transmission of Neospora caninum Between Wild and Domestic Animals

\author{
L. F. P. Gondim \\ University of Illinois, Urbana
}

M. M. McAllister

University of Illinois, Urbana

N. E. Mateus-Pinilla

Natural History Survey, Urbana, Illinois

W. C. Pitt

USDA-APHIS-WS

L. D. Mech

USGS Northern Prairie Wildlife Research Center, david_mech@usgs.gov

See next page for additional authors

Follow this and additional works at: https://digitalcommons.unl.edu/usgsnpwrc

Part of the Other International and Area Studies Commons

Gondim, L. F. P.; McAllister, M. M.; Mateus-Pinilla, N. E.; Pitt, W. C.; Mech, L. D.; and Nelson, M. E., "Transmission of Neospora caninum Between Wild and Domestic Animals" (2004). USGS Northern Prairie Wildlife Research Center. 104.

https://digitalcommons.unl.edu/usgsnpwrc/104

This Article is brought to you for free and open access by the US Geological Survey at DigitalCommons@University of Nebraska - Lincoln. It has been accepted for inclusion in USGS Northern Prairie Wildlife Research Center by an authorized administrator of DigitalCommons@University of Nebraska - Lincoln. 


\section{Authors}

L. F. P. Gondim, M. M. McAllister, N. E. Mateus-Pinilla, W. C. Pitt, L. D. Mech, and M. E. Nelson 


\title{
TRANSMISSION OF NEOSPORA CANINUM BETWEEN WILD AND DOMESTIC ANIMALS
}

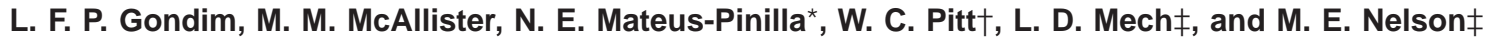 \\ Department of Veterinary Pathobiology, College of Veterinary Medicine, University of Illinois, 2001 South Lincoln Avenue, Urbana, Illinois \\ 61802. e-mail: pita@ufba.br
}

\begin{abstract}
To determine whether deer can transmit Neospora caninum, brains of naturally infected white-tailed deer (Odocoileus virginianus) were fed to 4 dogs; 2 of these dogs shed oocysts. Oocysts from 1 of the dogs were tested by polymerase chain reaction and found to be positive for $N$. caninum and negative for Hammondia heydorni. The internal transcribed spacer 1 sequence of the new strain (designated NC-deer1) was identical to $N$. caninum from domestic animals, indicating that $N$. caninum is transmitted between wild and domestic animals, often enough to prevent divergent evolution of isolated populations of the parasite. NC-deer1 oocysts were administered to a calf that developed a high antibody titer, providing evidence that $N$. caninum from wildlife can infect cattle. In addition, $N$. caninum antibody seroprevalence was detected in 64/164 (39\%) free-ranging gray wolves (Canis lupus), 12/113 (11\%) coyotes (Canis latrans), 50/193 (26\%) white-tailed deer, and 8/61 (13\%) moose (Alces alces). These data are consistent with a sylvatic transmission cycle of $N$. caninum between cervids and canids. We speculate that hunting by humans favors the transmission of $N$. caninum from deer to canids, because deer carcasses are usually eviscerated in the field. Infection of canids in turn increases the risk of transmitting the parasite to domestic livestock.
\end{abstract}

Neospora caninum is a protozoan parasite originally reported in dogs and calves (Bjerkås et al., 1984; O’Toole and Jeffrey, 1987; Parish et al., 1987; Dubey et al., 1988) and commonly diagnosed in bovine abortions worldwide (Dubey, 1999). The parasite has been detected in several mammalian species, i.e., sheep, goats, horses, deer (Dubey and Lindsay, 1996), water buffaloes (Guarino et al., 2000), rhinoceros (Williams et al., 2002), and foxes (Almeria et al., 2002). Dogs were the firstdiscovered definitive host of $N$. caninum (McAllister et al., 1998); recently, coyotes (Canis latrans) were also demonstrated to be definitive hosts of the parasite (Gondim, McAllister et al., 2004). When investigating $N$. caninum in canine feces, it is necessary to avoid confusion with the closely related parasite Hammondia heydorni, which has oocysts that appear similar to those of $N$. caninum (Slapeta et al., 2002). There are few confirmed cases of neosporosis in wild animals; however, antibodies against $N$. caninum have been found in several wild mammalian species, suggesting that the parasite may be widely spread among wildlife (for review, see Dubey, 2003).

Natural cases of neosporosis have been reported in different species of wild and captive deer (Woods et al., 1994; Dubey et al., 1996). The seroprevalence of $N$. caninum in free-ranging white-tailed deer (Odocoileus virginianus) in some states of the United States has been shown to be between 40 and 50\% (Dubey et al., 1999; Lindsay et al., 2002), suggesting that deer may play an important role in the epidemiology of neosporosis.

The aims of this study were to investigate whether naturally infected white-tailed deer tissues can induce dogs to shed $N$. caninum oocysts and to determine the prevalence of antibodies against $N$. caninum in serum samples from gray wolves (Canis lupus), coyotes, white-tailed deer, and moose (Alces alces). All sera were also tested for Toxoplasma gondii antibodies to rule out potential cross-reactivity between the 2 parasites.

Received 20 February 2004; revised 29 March 2004; accepted 30 March 2004.

* Center for Wildlife Ecology, Natural History Survey, Urbana, Illinois 61820.

† USDA-APHIS-WS, National Wildlife Research Center, Hilo Field Station, P.O. Box 10880, Hilo, Hawaii 96721.

$\ddagger$ U.S. Geological Survey, Northern Prairie Wildlife Research Center, 8711, 37th Street SE, Jamestown, North Dakota 58401-7317.

\section{MATERIALS AND METHODS}

\section{Collection of deer samples}

In December 2001, 30 blood samples were collected from the thoracic cavity of hunted white-tailed deer. The samples were selected from hunter-killed deer at the Vermillion County Illinois Department of Natural Resources (IDNR) deer check station in Illinois during the statewide firearm deer harvest season. The sera were tested for $N$. caninum antibodies to estimate the regional seroprevalence. In December 2002, with permission from IDNR, 12 deer heads with matching blood samples were collected from hunter-killed white-tailed deer in the same region. Heads from 4 deer with $N$. caninum antibody titer $\geq 1: 800$ by an indirect fluorescent antibody test (IFAT) (described in the Prevalence of Neospora caninum and Toxoplasma gondii Antibodies Using Wolf, Coyote, White-Tailed Deer, and Moose Sera) were selected and kept at $4 \mathrm{C}$ for up to $12 \mathrm{hr}$ after collection.

\section{Infection of dogs}

Four female mixed-breed hound puppies (A, B, C, and D), 10-14 wk old, purchased from a commercial class A breeder (Covance, Inc., Madison, Wisconsin), were housed individually in indoor kennels. The dogs were fed dry dog food and had never consumed raw meat or meat products. Each pup tested negatively for antibodies against $N$. caninum by IFAT $(<1: 25)$ before the experimental challenge.

Fecal samples from each dog were examined for 4 consecutive days before consuming the infected tissues. Within $12 \mathrm{hr}$ after collection of the deer heads, each dog was fed 1 whole brain from a seropositive deer. Fecal samples were examined daily for oocysts, starting on the third day after infection.

\section{Fecal examinations and processing of oocysts}

Dog feces were examined by a standard sucrose flotation technique, as described previously (Gondim et al., 2002). Fecal specimens containing oocysts were mixed with 5 volumes of $2 \% \mathrm{H}_{2} \mathrm{SO}_{4}$ and aerated for 3 days to induce sporulation. Sporulated oocysts were stored at $4 \mathrm{C}$ until used.

\section{DNA extraction from sporulated oocysts}

A volume of $140 \mathrm{ml}$ of dog feces diluted in $2 \% \mathrm{H}_{2} \mathrm{SO}_{4}$, containing 700 oocysts, was filtered through a gauze and distributed in $15-\mathrm{ml}$ centrifuge tubes. The tubes were centrifuged at $800 \mathrm{~g}$ for $10 \mathrm{~min}$, the supernatant was discarded, and the sediment was suspended with sucrose solution. Coverslips were placed on each tube, and the samples were centrifuged at $800 \mathrm{~g}$ for $10 \mathrm{~min}$. The coverslips were removed and washed in water to collect the oocysts. The solution containing the oocysts was centrifuged; the sediment was transferred to a $1.5-\mathrm{ml}$ tube, treated for $5 \mathrm{~min}$ with $2.6 \%$ sodium hypochlorite, and washed 5 times in water. The sediment was mixed with $700 \mu$ l of digestion buffer (100 $\mathrm{mM} \mathrm{NaCl}, 10 \mathrm{mM}$ Tris- $\mathrm{HCl}, \mathrm{pH} 8.0,25 \mathrm{mM}$ ethylenediaminetetraacetic acid [EDTA], $0.5 \%$ sodium dodecyl sulfate) and $5 \mu$ l of proteinase $\mathrm{K}$ $(20 \mathrm{mg} / \mathrm{ml})$ and added to a $1.5-\mathrm{ml}$ tube containing $500 \mu \mathrm{l}$ of glass beads 
TABLE I. IFAT for IgG antibodies against Neospora caninum and Toxoplasma gondii in sera from wildlife from several states of the United States.

\begin{tabular}{|c|c|c|c|c|c|c|}
\hline \multirow[b]{2}{*}{ Animal species } & \multirow[b]{2}{*}{ State } & \multicolumn{2}{|c|}{$N$. caninum IFAT } & \multicolumn{2}{|c|}{ T. gondii IFAT } & \multirow{2}{*}{$\begin{array}{l}\text { IFAT positive for } \\
\text { both } N \text {. caninum } \\
\text { and } T . \text { gondii }\end{array}$} \\
\hline & & Positive & Total $(\%)$ & Positive & Total $(\%)$ & \\
\hline \multirow[t]{3}{*}{ Coyote } & Utah & $1 / 45 \quad(2.2 \%)$ & & $6 / 45 \quad(13.3 \%)$ & & \\
\hline & Colorado & $5 / 28 \quad(17.9 \%)$ & 10.6 & $4 / 28 \quad(14.3 \%)$ & 31.0 & $6 / 113(5.3 \%)$ \\
\hline & Illinois & $6 / 40 \quad(15.0 \%)$ & & $25 / 40 \quad(62.5 \%)$ & & \\
\hline Moose & Minnesota & $8 / 61 \quad(13.1 \%)$ & 13.1 & $1 / 61 \quad(1.6 \%)$ & 1.6 & 0 \\
\hline
\end{tabular}

( $0.5 \mathrm{~mm}$ in diameter). The suspension was vortexed for $10 \mathrm{~min}$ and incubated at $65 \mathrm{C}$ for $2 \mathrm{hr}$. DNA was extracted using standard phenolchloroform followed by 2-propanol precipitation.

\section{Polymerase chain reaction assays for Neospora caninum and Hammondia heydorni}

DNA extracted from the oocysts was used in polymerase chain reaction (PCR) assays for $N$. caninum and H. heydorni. PCR for $N$. caninum was performed using the species-specific primer pair Np21-Np6 (Yamage et al., 1996). PCR conditions comprised 40 cycles at $94 \mathrm{C}$ for $1 \mathrm{~min}, 54 \mathrm{C}$ for $1 \mathrm{~min}$, and $72 \mathrm{C}$ for $1.5 \mathrm{~min}$, with a final extension step at $72 \mathrm{C}$ for $2 \mathrm{~min}$. DNA from $N$. caninum and Vero cells were used as positive and negative controls, respectively. PCR to detect $H$. heydorni was performed using the species-specific primers JS4-JS5 and PCR conditions described by Slapeta et al. (2002); a positive control ( $H$. heydorni DNA) and a negative control (Vero cell DNA) were included in the test. Each PCR reaction was performed in a $25-\mu 1$ volume containing $30 \mathrm{pmol}$ of each primer, $1.25 \mathrm{U}$ of Taq DNA polymerase, $200 \mu \mathrm{M}$ of each deoxynucleoside triphosphate, $1 \mu \mathrm{l}$ of template, 1.5 $\mathrm{mM} \mathrm{MgCl} 2,20 \mathrm{mM}$ Tris- $\mathrm{HCl}(\mathrm{pH} 8.4), 50 \mathrm{mM} \mathrm{KCl}$, and sterile $\mathrm{dd}_{2} \mathrm{O}$ up to $25 \mu 1$. PCR products were electrophoresed on $2.0 \%$ agarose gel stained with ethidium bromide in a $0.5 \times$ TBE buffer $(45 \mathrm{mM}$ Tris base, $45 \mathrm{mM}$ boric acid, $1 \mathrm{mM}$ EDTA, pH 8.0) at $100 \mathrm{~V}$ for $1 \mathrm{hr}$ and observed under ultraviolet (UV) illumination.

\section{Internal transcribed spacer 1 sequencing}

Extracted DNA from oocysts was used for amplification and sequencing of the internal transcribed spacer 1 (ITS1) region of the ribosomal DNA (rDNA). PCR for the ITS1 was performed using the primers ITS5-ITS2 (White et al., 1990); PCR conditions consisted of an initial denaturing step at $94 \mathrm{C}$ for 3 min followed by 30 cycles at $94 \mathrm{C}$ for 1 $\min , 55 \mathrm{C}$ for $1 \mathrm{~min}$, and $72 \mathrm{C}$ for $2 \mathrm{~min}$, with a final extension step at $72 \mathrm{C}$ for $7 \mathrm{~min}$. DNA of $N$. caninum (NC-beef strain) (Gondim, Laski et al., 2004) and Vero cells were included as positive and negative controls, respectively, in the PCR assays. The products were electrophoresed on $1.5 \%$ agarose gel stained with ethidium bromide at $100 \mathrm{~V}$ for $1 \mathrm{hr}$ and gel purified using the QIAquick Gel Extraction Kit (Qiagen Inc., Valencia, California). Automated sequence reactions for N. caninum ITS1 were performed at the Biotechnology Center at the University of Illinois at Urbana-Champaign, using the internal primers PN1PN2 (Holmdahl and Mattsson, 1996).

\section{PCR-amplified ITS1 using 5\% polyacrylamide gel electrophoresis}

The amplified ITS1 from the recently isolated oocysts and from the $N$. caninum strain NC-beef (positive control) were electrophoresed on $5 \%$ polyacrylamide gel (BioRad, Ready gel, Hercules, California) at $120 \mathrm{~V}$ for $2 \mathrm{hr}$. The gel was stained with ethidium bromide and observed by UV illumination.

\section{Oral inoculation of a calf with oocysts shed by a dog that} consumed infected deer brain

A newborn dairy bull calf was purchased from the University of Illinois Dairy. It was housed indoors on a slatted floor, without bedding, and fed milk replacer. The calf was seronegative for $N$. caninum anti- bodies at 1:25 by IFAT. At 5 days of age, the calf received 2,500 sporulated oocysts shed by $\operatorname{dog} \mathrm{A}$, through an esophageal feeder. Blood was collected from the calf 34 days after administration of oocysts, and the serum was separated and kept at $-20 \mathrm{C}$ until examined.

\section{Prevalence of Neospora caninum and Toxoplasma gondii} antibodies using wolf, coyote, white-tailed deer, and moose sera

Sera from 164 gray wolves, 113 coyotes, 193 white-tailed deer, and 61 moose were examined (Table I). Wolf and moose sera were collected in northeastern Minnesota, coyote sera were collected in Utah, Colorado, and Illinois, and sera from white-tailed deer were collected in northeastern Minnesota and Illinois. All sera had been collected previously for use in other investigations. IFATs were used for the detection of antibodies against $N$. caninum and $T$. gondii using tachyzoites of the strains NC-beef and RH as antigens, respectively. A fluorescein isothiocyanate (FITC)-conjugated anti-dog IgG (Bethyl, Montgomery, Texas), diluted at 1:50 in phosphate-buffered saline (PBS), was used as a secondary antibody for wolf and coyote sera; FITC-conjugated antideer IgG (Cappel, Durham, North Carolina), diluted at 1:50 in PBS, was used for white-tailed deer and moose sera. Sera reacting at dilutions $\geq 1: 50$ were considered positive for $T$. gondii antibodies. For $N$. caninum serology, deer and moose sera were considered positive if they reacted at dilutions $\geq 1: 100$, and 1:50 was selected as the cutoff for coyote and wolf sera. The maximum antibody titer was determined for all $N$. caninum-positive samples. Maximum titers for $T$. gondii were determined only for samples that showed positive reactions for both $T$. gondii and $N$. caninum.

\section{RESULTS}

\section{Oocyst shedding and PCR from oocyst DNA}

Two of 4 dogs (A and B) that ingested naturally infected deer brain shed $N$. caninum-like oocysts in the feces. Dog A shed approximately 12,300 oocysts between 7 and 14 days after infection; $\operatorname{dog}$ B shed approximately 500 oocysts on the 11th and 12th days after infection. Oocysts were shed unsporulated and measured $10 \mu \mathrm{m}$ in diameter $(\operatorname{dog} \mathrm{A}, \mathrm{n}=10 ; \operatorname{dog} \mathrm{B}, \mathrm{n}=$ $5)$. Sporulation was induced when oocysts were mixed in $2 \%$ $\mathrm{H}_{2} \mathrm{SO}_{4}$ and aerated at room temperature for 3 days. The oocysts shed by dog A tested positively for $N$. caninum by PCR (Fig. 1 ); in contrast, PCR for $H$. heydorni yielded negative results. DNA could not be extracted from dog B oocysts, which were in low numbers and diluted in a large volume of feces. The 4 dogs remained seronegative for $N$. caninum antibodies at 1:50 by IFAT 28 days after consuming deer brain.

\section{ITS1 sequence of the recently isolated oocysts}

The ITS1 sequence obtained from the recently isolated $N$. caninum oocysts (designated NC-deer1) (GenBank AY508811) was identical to the ITS1 sequence of the $N$. caninum strain 


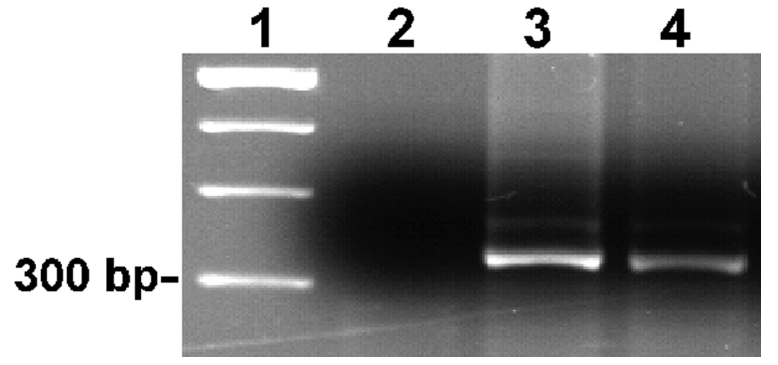

FIGURE 1. PCR for Neospora caninum using Np21-Np6 primers (Yamage et al., 1996). (1) A 100-bp DNA ladder; (2) Vero cell DNA (negative control); (3) N. caninum DNA (positive control); and (4) a positive reaction for $N$. caninum using DNA extracted from oocysts of the newly described isolate from deer (designated NC-deer1).

NC-Illinois, which had been isolated from a dairy calf in Illinois (Gondim, Laski et al., 2004) (GenBank AY259041), and to other $N$. caninum ITS1 sequences of dogs or cattle (strain/ accession number: NC-2/AF249969, NC-5/AF249970, BPA1/ AF038860, CN1/AF038861, NC-SweB1/AF029702, NC-beef/ AF249968, CZ-4/AF432123). The PCR-amplified product of the NC-deer1 using the primers ITS5-ITS2 yielded a band of approximately 510 base pairs (bp) on the $1.5 \%$ agarose gel (Fig. 2A); this band comprises the reported ITS1 sequence for $N$. caninum (421 bp) and part of the $18 \mathrm{~S}$ and 5.8S rDNA genes. The same PCR-amplified ITS 1 of the NC-deer1 isolate was observed as 2 distinct bands on 5\% polyacrylamide gel electrophoresis (PAGE), identical to the NC-beef strain that was used as a positive control (Fig. 2B) and similar to other strains examined previously (Gondim, Laski et al., 2004).

\section{Serological response of the calf infected with the newly isolated oocysts}

A newborn dairy bull calf developed an antibody titer of 1 : 800 to $N$. caninum 34 days after oral inoculation with 2,500 oocysts of the newly described isolate (NC-deer1).

\section{Serology of wild animals}

Antibodies against $N$. caninum were detected in $39 \%$ of wolves, $11 \%$ of coyotes, $26 \%$ of white-tailed deer, and $13 \%$ of moose. Antibodies to T. gondii were found in $29 \%$ of wolves, $31 \%$ of coyotes, $12 \%$ of white-tailed deer, and $2 \%$ of moose; positive reactions for both $N$. caninum and $T$. gondii were observed in $14 \%$ of wolves, $5 \%$ of coyotes, $3 \%$ of white-tailed deer, and $0 \%$ of moose (Table I). The maximum $N$. caninum antibody titer observed in wolf and moose sera was 1:6,400; titers up to 1:3,200 were found in white-tailed deer, and in coy-

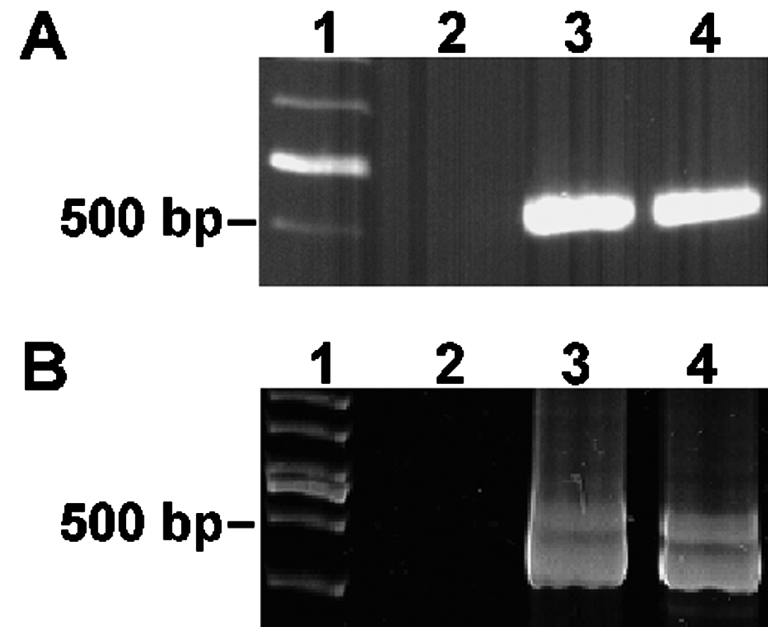

FIGURE 2. PCR amplification of the ITS1 region. (1) A 100-bp DNA ladder; (2) Vero cell DNA (negative control); (3) Neospora caninum DNA (positive control); and (4) DNA extracted from the NC-deer1 isolate. (A) On a $1.5 \%$ agarose gel, a single band of approximately 510 bp was observed for the NC-deer1 isolate and also for the $N$. caninum DNA used as positive control. (B) On a 5\% polyacrylamide gel, which has a higher resolution than the $1.5 \%$ agarose gel, 2 distinct bands were observed for each PCR-amplified product.

otes the maximum serum titer against the protozoan was 1:800 (Table II). In a total of $133 \mathrm{~N}$. caninum-positive serum samples observed for all tested animals, 98 sera reacted solely with $N$. caninum and 35 sera reacted with both $N$. caninum and $T$. gondii (Table I).

\section{DISCUSSION}

Two of the 4 dogs shed $N$. caninum-like oocysts after ingesting brain of naturally infected white-tailed deer. Oocysts shed by 1 dog (A) were confirmed to be $N$. caninum using the specific primers Np21-Np6 and by sequencing the ITS1 region of the rDNA. PCR for $H$. heydorni was negative. A calf that ingested these oocysts developed an $N$. caninum antibody titer of $1: 800,34$ days after inoculation.

The ITS 1 of the rDNA is a region that evolves fast and has frequently been used for phylogenetic comparisons among different organisms (White et al., 1990). The ITS1 sequence of the new $N$. caninum isolate (NC-deer1) is identical to the ITS1 sequence reported for $N$. caninum strains isolated from domestic animals (Gondim, Laski et al., 2004). The separation of the amplified ITS1 into 2 distinct bands on 5\% PAGE, as recently reported for 6 different strains of $N$. caninum (Gondim, Laski et al., 2004), was also observed for the ITS1 region of NC-

TABLE II. Neospora caninum antibody titers in seropositive wolves, coyotes, white-tailed deer, and moose, tested by IFAT.

\begin{tabular}{|c|c|c|c|c|c|c|c|c|}
\hline \multirow[b]{2}{*}{ Animals } & \multicolumn{8}{|c|}{ Serum dilution } \\
\hline & $1: 50$ & $1: 100$ & $1: 200$ & $1: 400$ & $1: 800$ & $1: 1,600$ & $1: 3,200$ & $1: 6,400$ \\
\hline Wolves & 8 & 7 & 9 & 12 & 14 & 10 & 3 & 1 \\
\hline Coyotes & 3 & 6 & 1 & 1 & 1 & 0 & 0 & 0 \\
\hline White-tailed deer & $\mathrm{ND}^{*}$ & 9 & 10 & 3 & 15 & 7 & 6 & 0 \\
\hline Moose & $\mathrm{ND} *$ & 2 & 1 & 1 & 2 & 0 & 1 & 1 \\
\hline
\end{tabular}

\footnotetext{
$* \mathrm{ND}=$ not determined.
} 


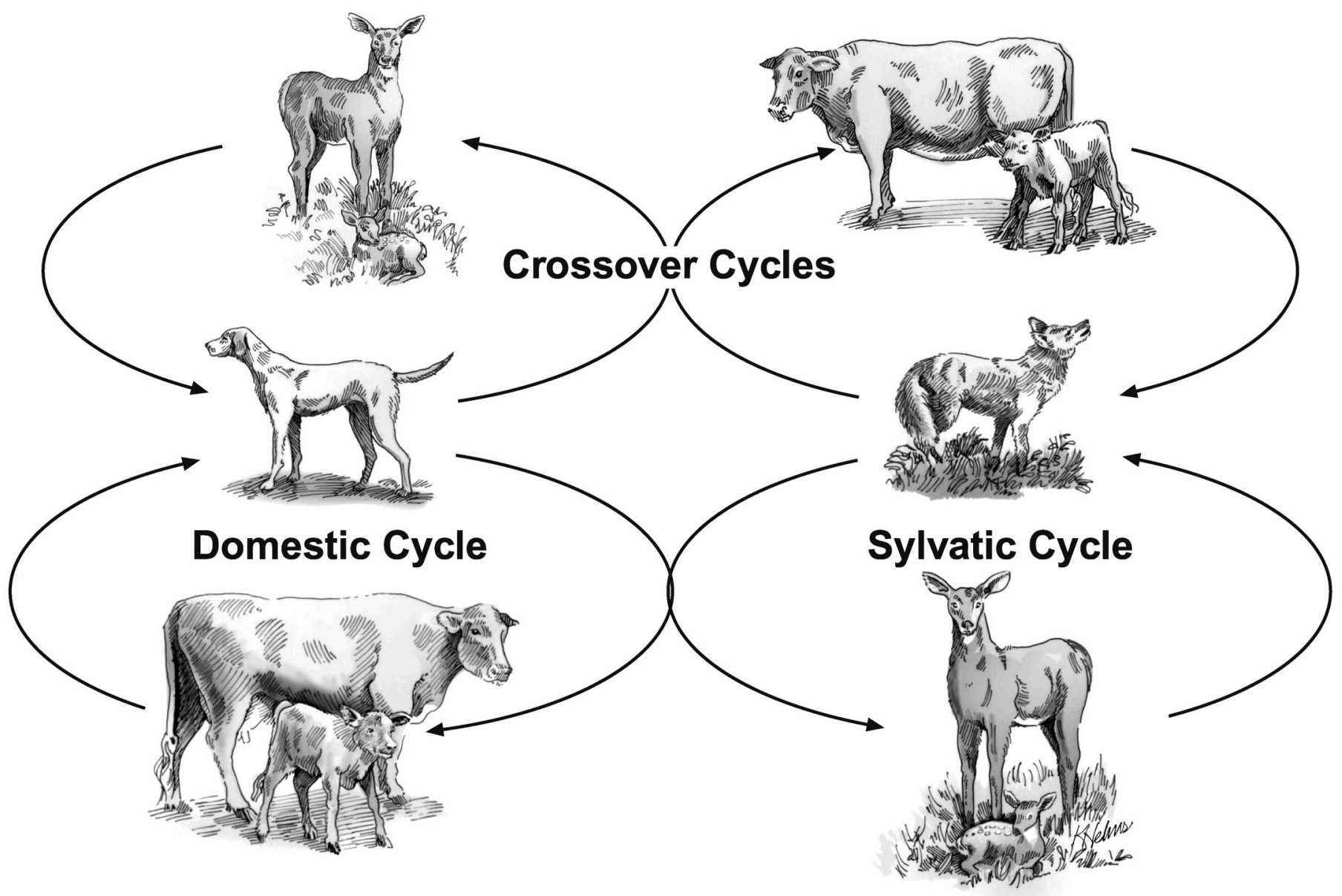

FIGURE 3. Transmission cycles of the protozoan Neospora caninum between wild and domestic animals. The domestic cycle, transmission from cattle to coyotes, and transmission from deer to dogs have each been demonstrated. Transmission between coyotes and deer, from coyotes to cattle, and from dogs to deer are probable but as yet untested.

deer1. These results indicate that $N$. caninum infections are horizontally transmitted between wild and domestic animals, often enough to prevent divergent evolution of isolated populations of the parasite.

In this investigation, wild naturally infected deer transmitted $N$. caninum to dogs. In a previous study (Gondim, McAllister et al., 2004), coyotes were shown to be a definitive host of $N$. caninum when they shed oocysts after ingesting tissues from infected cattle. Based on these findings, a crossover cycle of $N$. caninum between wild and domestic animals is proposed and illustrated in Figure 3.

In this study, deer brain was the only tissue fed to dogs because we wanted to avoid shedding of Sarcocystis spp. sporocysts in feces, which could have complicated observation and identification of $N$. caninum oocysts. Sarcocystis spp. are commonly observed in skeletal muscle and heart of wild deer (Emnett and Huggins, 1982). In a previous study (Gondim et al., 2002 ), the production of $N$. caninum oocysts in dogs was improved by providing the dogs various tissues from experimentally infected calves, including brain, spinal cord, heart, skeletal muscle, diaphragm, and kidney. Hence, dogs consuming a mixture of different tissues from deer might have shed a greater number of oocysts than that observed in this experiment. The
4 deer brains used in this study were collected from $N$. canin$u m$-seropositive deer; however, it is not known whether all the 4 selected brains contained cysts of the parasite.

White-tailed deer are easily adaptable to a variety of environmental conditions and are widely distributed in North America. In 1998, the number of white-tailed deer in North America was estimated to be almost 29 million in the winter; hunters harvest about 6 million white-tailed deer annually (Crête and Daigle, 1998). When deer are hunted, carcasses are usually field dressed and the offal is left behind. Besides the natural predation of deer by wild canids, during every deer-hunting season the offal is readily available for consumption by wild canids and dogs, which could increase the risk of transmission of $N$. caninum from canids to livestock.

The prevalence of $N$. caninum antibodies found in wolves, coyotes, white-tailed deer, and moose ranged from 11 to $39 \%$. Antibody titers up to 1:6,400 were observed in wolf and moose, titers up to 1:3,200 were found in white-tailed deer, and titers up to 1:800 were found in coyotes; these findings suggest that a wild canid-ruminant life cycle of the parasite is common. All serum samples used in this survey were tested for both $N$. caninum and T. gondii; in 133 samples that tested positive for $N$. caninum antibodies, more than $70 \%$ of these samples reacted 
solely to $N$. caninum, indicating that $N$. caninum titers were not an artifact of cross-reaction with $T$. gondii. The high prevalence (39\%) and high titers (up to 1:6,400) of $N$. caninum antibodies observed in wolves are probably related to their diet, which is mostly based on ruminants, including white-tailed deer and moose; wolves may be exposed to $N$. caninum-infected tissues repeatedly throughout their lives. Antibodies to $N$. caninum were found in $11 \%$ of coyotes; their diet is more diversified when compared with wolves and they do not primarily rely on ruminants (Arjo et al., 2002). Nevertheless, the prevalence of antibodies found in coyotes $(11 \%)$ is still higher than that reported for dogs in the United States (7\%) (Cheadle et al., 1999).

The isolation of $N$. caninum from wildlife, the serological evidence of infection in several wild animals, and the demonstration that the parasite can cycle between wild and domestic animals pose new questions about the relative importance of transmission of $N$. caninum between wildlife and livestock. Some reasonable control measures may help to prevent transmission of the parasite to domestic ruminants, such as protection of feedstuffs from contamination with canine feces and appropriate disposal of dead livestock to prevent consumption by a definitive host. The large amount of offal from hunted deer carcasses that are field dressed and left available for consumption by a variety of carnivores could pose an added risk of disease transmission each fall.

\section{ACKNOWLEDGMENTS}

We thank Mark Lenarz (Minnesota Department of Natural Resources), Michael Schrage (Fond du Lac Band of Lake Superior Chippewa, Minnesota), and Andrew Edwards (1854 Authority, Minnesota) for providing moose sera. We also thank Eric Gese (USDA-APHIS-WS, National Wildlife Research Center, Predator Research and Ecology, Logan, Utah) for providing wolf and coyote sera. This study was supported in part by USDA Hatch funds administered by the University of Illinois Agricultural Experimental Station (ILLU-70-0341) and by the Biological Resources Division, U.S. Geological Survey, and U.S. Department of Agriculture, North Central Research Station. Figure 3 was illustrated by Kerry Helms (College of Veterinary Medicine Biomedical Communication Center, University of Illinois). L.F.P.G. is the recipient of a fellowship from CNPq, Brazil. The H. heydorni DNA was kindly provided by John Ellis.

\section{LITERATURE CITED}

Almeria, S., D. Ferrer, M. Pabon, J. Castella, and S. Manas. 2002. Red foxes (Vulpes vulpes) are a natural intermediate host of Neospora caninum. Veterinary Parasitology 107: 287-294.

Arjo, W. M., D. H. Pletscher, and R. R. Ream. 2002. Dietary overlap between wolves and coyotes in Northwestern Montana. Journal of Mammology 83: 754-766.

BJERKÅs, I., S. F. MOHN, AND J. Presthus. 1984. Unidentified cystforming sporozoon causing encephalomyelitis and myositis in dogs. Zeitschrift für Parasitenkunde 70: 271-274.

Cheadle, M. A., D. S. Lindsay, and B. L. Blagburn. 1999. Prevalence of antibodies to Neospora caninum in dogs. Veterinary Parasitology 85: $325-330$.

Crête, M., And C. Daigle. 1998. Management of indigenous North American deer at the end of the 20th century in relation to large predators and primary production. Acta Veterinaria Hungarica 47: $1-16$.

Dubey, J. P. 1999. Recent advances in Neospora and neosporosis. Veterinary Parasitology 84: 349-367.
2003. Review of Neospora caninum and neosporosis in animals. Korean Journal of Parasitology 41: 1-16.

, J. L. Carpenter, C. A. Speer, M. J. Topper, and A. Uggla. 1988. Newly recognized fatal protozoan disease of dogs. Journal of the American Veterinary Medical Association 192: 1269-1285. , K. Hollis, S. Romand, P. Thulliez, O. C. Kwok, L. HungerFORD, C. ANCHOR, AND D. ETTER. 1999. High prevalence of antibodies to Neospora caninum in white-tailed deer (Odocoileus virginianus). International Journal for Parasitology 29: 1709-1711. - AND D. S. LindSAY. 1996. A review of Neospora caninum and neosporosis. Veterinary Parasitology 67: 1-59.

, J. Rigoulet, P. Lagourette, C. George, L. Longeart, and J. L. LENET. 1996. Fatal transplacental neosporosis in a deer (Cervus eldi siamensis). Journal of Parasitology 82: 338-339.

EmnetT, C. W., And E. J. Huggins. 1982. Sarcocystis of deer in South Dakota. Journal of Wildlife Diseases 18: 187-193.

Gondim, L. F. P., L. GAO, AND M. M. McAllister. 2002. Improved production of Neospora caninum oocysts, cyclical oral transmission between dogs and cattle, and in vitro isolation from oocysts. Journal of Parasitology 88: 1159-1163.

, P. LAski, L. GAO, AND M. M. MCAllister. 2004. Variation of the internal transcribed spacer 1 (ITS1) sequence within individual strains and among different strains of Neospora caninum. Journal of Parasitology 90: 119-122.

-, M. M. McAllister, W. C. Pitt, And D. E. ZemlickA. 2004. Coyotes (Canis latrans) are definitive hosts of Neospora caninum. International Journal for Parasitology 34: 159-161.

Guarino, A., G. Fusco, G. Savini, G. Di Francesco, and G. Cringoli. 2000. Neosporosis in water buffalo (Bubalus bubalis) in Southern Italy. Veterinary Parasitology 91: 15-21.

Holmdahl, O. J., AND J. G. MAtTsson. 1996. Rapid and sensitive identification of Neospora caninum by in vitro amplification of the internal transcribed spacer 1. Parasitology 112: 177-182.

Lindsay, D. S., S. E. LitTle, And W. R. Davidson. 2002. Prevalence of antibodies to Neospora caninum in white-tailed deer, Odocoileus virginianus, from the southeastern United States. Journal of Parasitology 88: 415-417.

McAllister, M. M., J. P. Dubey, D. S. Lindsay, W. R. Jolley, R. A. Wills, AND A. M. MCGuire. 1998. Dogs are definitive hosts of Neospora caninum. International Journal for Parasitology 28: 1473-1478.

O'TOOLE, D., AND M. JeFFrey. 1987. Congenital sporozoan encephalomyelitis in a calf. Veterinary Record 121: 563-566.

Parish, S. M., L. MaAg-Miller, T. E. Besser, J. P. Weidner, T. McElwain, D. P. Knowles, and C. W. Leathers. 1987. Myelitis associated with protozoal infection in newborn calves. Journal of the American Veterinary Medical Association 191: 1599-1600.

Slapeta, J. R., B. Koudela, J. Votypka, D. Modry, R. Horejs, And J. LUKES. 2002. Coprodiagnosis of Hammondia heydorni in dogs by PCR based amplification of ITS 1 rRNA: Differentiation from morphologically indistinguishable oocysts of Neospora caninum. Veterinary Journal 163: 147-154.

White, T. J., T. Bruns, S. Lee, And J. TAYlor. 1990. Amplification and direct sequencing of fungal ribosomal RNA genes for phylogenetics. In PCR protocols, a guide to methods and applications, M. A. Innis, D. J. Gelfand, J. J. Sninsky, and T. J. White (eds.). Academic Press, San Diego, California, p. 315-322.

Williams, J. H., I. Espie, E. Van Wilpe, And A. Matthee. 2002. Neosporosis in a white rhinoceros (Ceratotherium simum) calf. Journal of the South African Veterinary Association 73: 38-43.

Woods, L. W., M. L. Anderson, P. K. Swift, and K. W. Sverlow. 1994. Systemic neosporosis in a California black-tailed deer (Odocoileus hemionus columbianus). Journal of Veterinary Diagnostic Investigation 6: 508-510.

Yamage, M., O. Flechtner, And B. GotTstein. 1996. Neospora caninum: Specific oligonucleotide primers for the detection of brain "cyst" DNA of experimentally infected nude mice by the polymerase chain reaction (PCR). Journal of Parasitology 82: 272-279. 